\title{
Ordovician Meiklejohn bioherm, Nevada
}

SIR - Renewed interest in the origin and sedimentological significance of stromatactis and of zebra rock has recently been stimulated by the publication of a USGS Professional Paper on the Ordovician Meiklejohn bioherm in Nevada (Ross, Jaanusson \& Friedman, 1975), compiled by three experienced geologists who, moreover, have sought the advice of numerous equally distinguished colleagues. Whatever view may be taken of their conclusions, these unquestionably demand respectful attention. Furthermore, the authors have demonstrated the urgent need for more research into these two sedimentary structures, a greater understanding of which is essential if we are to comprehend the growth of Palaeozoic carbonate bioherms. In this letter I attempt to assess, and in part to challenge, the conclusions reached in USGS Professional Paper 871.

To begin with, even dissenting readers must acknowledge the high level of presentation and of discussion in this most useful report on a controversial subject. All too rarely are factual data displayed so fully and so lucidly as they are here, so that the reader may judge for himself the validity of the authors' conclusions. No attempt is made to disguise some evident disagreement among the authors. The modest title of the paper belies both the significance of the publication and the wide interest that it must arouse. This is, above all, a report on the origins of stromatactis and zebra limestone, fabrics that occur in carbonate bioherms in many parts of the world with ages at least from Cambrian to Pennsylvanian. Inevitably the paper is a major test of our ability to identify unambiguously the products and precursors of neomorphic alteration. The paper is also a welcome reminder that stromatactis is not, as recently proposed, a mere synonym for cavity, but is a very special kind of cavity with peculiar difficulties attaching to its interpretation. Careless misuse of this petrographic term (despite clear and unequivocal published descriptions) has tended of late to hide the very real problems of its origins and thus to discourage research into its geological significance. A similar fate nearly befell radiaxial fibrous calcite, which plays so important a part in stromatactis and zebra limestone. Fortunately this fabric was rescued from the hands of those who saw in the original description only what they found convenient, and has been made the subject of a careful analysis and interpretation by Kendall \& Tucker (1973) - an interpretation that is of fundamental significance in the discussion of the origin of the limestones in the bioherm at Meiklejohn Peak.

The paper on the Meiklejohn bioherm begins with a general description of its setting, after which Ross describes the lithology of the zebra limestone and Jaanusson that of the core facies with stromatactis. Friedman then gives an account and analysis of the data for $\delta^{13} \mathrm{C}$ and $\delta^{18} \mathrm{O}$. Finally Ross puts forward an interpretation of zebra rock with emphasis on the radiaxial fibrous calcite, with which Jaanusson is not in full agreement (text and personal communication). The origin of the masses of radiaxial fibrous calcite relates as much to stromatactis as to zebra limestone and it is upon this central problem that the following examination will be concentrated.

Briefly, zebra limestone is made essentially of repeated $a b c$ cycles which, when complete, consist of fossiliferous calcilutite at the base, followed unconformably by a pelletoid calcilutite which is capped, again unconformably, by an equigranular calcilutite which may pass laterally and abruptly into radiaxial fibrous calcite. These last two lateral equivalents are covered by the fossiliferous calcilutite at the base of the overlying cycle. (Incidentally, it is important to note the limitations of the old Grabau classification, used by Ross, compared with the greater precision that would have accompanied the use of the more informative modern terminology of Folk or Dunham.) The abc cycles are about $1 \mathrm{~cm}$ thick and may extend laterally for at least $3 \mathrm{~m}$. The radiaxial fibrous calcite is partially described but reference is made to the description by Bathurst $(1959,1971)$. It shows the familiar increase of crystal size away from the margins of the masses, sutured intercrystalline boundaries and a median suture between upper and lower layers. Presumably it also possesses intracrystalline convergent fast vibration directions. Regrettably the matter of the orientation of the finer sparry crystals, where these abut against the enclosing sediment, is neglected. Nevertheless, inspection of the photomicrographs suggests the presence of the usual preferred orientation of long axes (and optic axes?) normal to the bounding surfaces and to the surfaces of shells filled with or embedded in this type of spar. The spar may be interrupted by more or less horizontal layers of pelletoids: the layers have flattish bottoms but irregular tops.

The masses of spar called stromatactis are embedded in calcilutite (biomicrite) and may compose up to $20 \%$ of the rock. Characteristically they have their major extensions parallel to the depositional surface and are rarely thicker than $2 \mathrm{~cm}$ and may be followed laterally for as much as $24 \mathrm{~cm}$. The floor is generally even to gently undulose but the roof varies from even to digitate. The radiaxial fibrous calcite is like that in the zebra limestone.

Geol. Mag. 114 (4), 1977, pp. 308-311. Printed in Great Britain. 
An interpretation of the masses of radiaxial fibrous calcite has been presented by Ross. The balance of his contention is that much or all of the radiaxial fibrous calcite is a neomorphic replacement of a pre-existing carbonate mud (calcilutite or biomicrite). To my mind, on the contrary, it is clearly a neomorphic replacement of an earlier cement that filled a cavity system.

To begin with, the authors state that 'field evidence suggests that the pelletoid calcilutite has been selectively replaced by or recrystallized into radiaxial calcite' or that 'radiaxial mosaic has demonstrably incorporated skeletal particles and grown at their expense'. I take issue with this contention, not simply because I regard it as mistaken, but more urgently because the authors do not make clear upon what evidence they build this conclusion. The captions of photomicrographs are commonly only interpretations rather than descriptions. The case put by Ross is asserted rather than argued, as if the distinction between cement spar (or precursor) and neomorphic spar were a trifling business and not - as is surely apparent - a problem requiring the application of precise logical argument based on carefully observed critical fabric criteria.

I have the impression that much of the fog of disputation would disperse if it were more clearly appreciated that the problem is not about whether the sparry calcite is a cement or a neomorphic spar. I doubt whether anyone nowadays would deny that radiaxial fibrous calcite is a neomorphic fabric, as shown by Kendall \& Tucker (1973) and as the authors themselves clearly believe. The argument is, surely, over the nature of the precursor which this spar has replaced. A solution to this problem has been put forward by Kendall \& Tucker in painstaking detail and it is sad that the significance of their work is not more widely appreciated. It is the peculiar origin of radiaxial fibrous calcite, as an in situ replacement of a pre-existing radial-fibrous precursor (commonly assumed to have been an aragonite cement), that gives it its highly organized form. It is from this special type of precursor that it has inherited its preferred orientation of longest axes and crystallographic axes, its intracrystalline convergent fast vibration directions, its divergent subcrystals and its increase in crystal size away from the wall. For this is a very highly organized fabric. In their figure 21 the authors of the Meiklejohn paper show radiaxial fibrous calcite with its various vectors oriented preferentially normally to the surfaces of the shells. This relation with the host surface is a basic characteristic of the fabric. It is known in stromatactis and other spar-filled cavities the world over. The vectors are oriented normally to surfaces that we know existed prior to the precipitation of the first cement. The existence of such host surfaces, either free surfaces of skeletal grains or free walls of cavities, are essential for the development of the precursors of any radiaxial fibrous calcite: this has never been seen without them. They are the single essential factor in the control of the vectorial orientation. It is, therefore, apparent that radiaxial fibrous calcite cannot grow by in situ replacement of a biomicrite (or of a wet unconsolidated carbonate mud) wherein no such controlling surfaces exist. This, I suggest, is the answer to Ross's cri de coeur where he asks, 'why should it [radiaxial fibrous calcite] not be derived even more readily from micritic aragonite or high-magnesian calcite?' Indeed, the evidence indicates that neomorphism here has been selective, attacking the original unstable radial-fibrous cement but ignoring the biomicrites.

The authors refer to skeletal grains apparently floating (but in two dimensions) in radiaxial fibrous calcite as evidence in support of neomorphic replacement of a biomicrite. Yet they do not record the orientation of the vectorial sparry fabrics where these meet the surfaces of the skeletal particles, despite the central position of this critical geometrical relation in the argument. Experience of stromatactis elsewhere reveals that the vectors in the radiaxial fibrous calcite have preferred orientations normal to the surfaces of such particles.

Elephant tracks converge on a pool because the animals can smell the water at a distance. Crystals do not have this faculty. If crystals of sparry calcite were to grow, at the expense of a biomicrite, upward and downward from a median suture, they would never bend solicitously toward the larger skeletal grains as they approached them. Crystals are blind! Grains surfaces do beckon! No fragment of bryozoan whispers to the neomorphic spar as it advances through the micritic gloom, 'Come live with me and be my love' - thus causing the growing calcite fibres to change course and to entwine themselves about the bryozoan with preferred orientation amourously disposed normally to its surface. Where neomorphic spar does grow outward from a point or surface in a carbonate mud it can certainly yield a preferred orientation, but this is related to the original growth point or surface, not to any bit of shell that may be engulfed as the front of the spar advances. If a skeletal grain is embedded in radiaxial fibrous calcite with fibres oriented normally to the grain surface, they or their precursor must have grown from that surface - either as primary cement or as neomorphic replacement of cement or carbonate mud. However, as most boundaries of the radiaxial fibrous calcite in zebra rock and stromatactis are not in any way related to such primary surfaces, they must be related to the only other primary surface available, namely the wall of a cavity. Ross's claim that the radiaxial fibrous calcite grew upward and downward from the median suture does not fit with the preferred orientation of crystals related to primary surfaces. 
Appeal is made in the Meiklejohn paper to the common presence, in the mass of radiaxial fibrous calcite, of a basal layer of this spar that lies at the bottom of the thick symmetrical layer with its median suture. The existence of this 'tier' clearly causes Ross immense difficulty in the attempted interpretation. The fabric of the basal tier differs in no way from that of the main mass of radiaxial fibrous calcite. It is distinguished only by a thin discontinuous covering of pelletoids that separates it from the overlying radiaxial calcite - nothing more. Followed laterally, the distinction between the 'early' tier and the overlying spar may disappear. Looking at the photomicrographs I am struck by the fact that always the patch of pelletoids has a flat or very gently undulose base but an irregular hummocky top. This top and bottom relation has always the same sense. Such a fabric was described by Sander in 1936, as a fundamental geopetal criterion (his polar belegte sedimentäre). It would arise where pelletoids were deposited on the floor in a cavity whose walls had already been encrusted with a smooth-topped layer of isopachous cement. This simple explanation fits the evidence presented in the Meiklejohn figures (especially Figs 9 and 10B). The author's concern, that such a relation must, unacceptably, imply early precipitation of a tier of cement on the floor before any was precipited on the roof, is seen to be unnecessary. Relevant to this discussion is a detailed and lucid comparison of Ordovician neomorphosed cements with their modern analogues (Davies, 1977).

Another argument used against the prior existence of cavities that were later filled with cement is the well known one that the cavity system must have occupied a substantial volume (more than half) of the sediment. It seems to Ross mechanically impossible that open galleries on such a scale could have been maintained. Yet we accept such an explanation for the structure of algal stromatolites. The author does refer briefly to the possibility of growth of successive lithified crusts a few millimetres thick, capable of sustaining underlying cavity systems long enough for them to be filled with early submarine cement. Unhappily, this simple explanation is not regarded favourably. Yet, surely, as a guiding principle, it is potentially valuable. Moreover, the photomicrographs show some cross-laminated pelsparites whose distribution relative to adjacent fabrics must make them, for many readers, some of the most strikingly convincing internal sediments (cavity fills) that could be imagined. It is worthy of note here that none of the fabrics illustrated in the Meiklejohn paper is any more complex or difficult to understand than the pictures of cavities with cement and sediment fills portrayed in the well known works of Schwarzacher, Lees, Zankl, Scoffin or Heckel.

Finally, on the subject of sparry calcite, it is disturbing to read that the formation of such sparry layers ' has had widely differing interpretations' (my italics), when, among the seven works referred to, five interpret the layers as cavity fills and two as recrystallized carbonate mud.

The isotopic data presented by Friedman are extremely interesting though not easy to understand. Certainly this author seems right in finding that the Bermuda model of freshwater diagenesis does not apply to the Meiklejohn case. But the isotopic data for the Bermuda model are themselves now in question because, coming from samples collected near the surface, they yield unduly negative ratios. Analyses of samples from cores give less negative isotopic ratios (Allan \& Mathews, in the press).

To my mind then, the zebra spar and stromatactis spar are neomorphosed products of early radial-fibrous (aragonitic?) cements. I remain unmoved by the cry, 'We know of no way to explain precipitation of sparry or radiaxial fibrous calcite', etc., in such and such a situation. This to my mind is no reason for turning a blind eye to unambiguous fabric criteria. I can see no good reason for not supposing that syndepositional radial-fibrous masses grew upward, downward and sideways into a cavity and that they had flat or gently undulose growth fronts: such growth patterns, with the symmetrical zoning, are typical of this kind of material. They then met and formed the gentle median suture. Any pelletoids that found their way into the cavity were trapped on the current lower growth surface of the cement (the 'tier') and buried by later cement. This precipitation was interrupted from time to time by the deposition of cross-laminated internal sediments. A brachiopod projecting downward from the roof, to which the authors draw attention in their Fig. 10C, would simply indicate some erosion of partly lithified roof material prior to cement filling of the cavity, as shown also by the 'umbrella' effect of some shells. That the origin of the cavity system is at present inexplicable is no reason for denying its one-time existence. Furthermore, it seems regrettable that, after twenty years of progress in the petrology of carbonate sediments, 'recrystallization', or more fashionably 'aggrading neomorphism', should still be treated as a rag bag into which we can drop anything that we do not understand.

The Meiklejohn paper offers a wealth of useful evidence, clearly and fairly presented, but my impression is that Ross stumbles needlessly over imaginary obstacles where all the data are, in fact, neatly consistent with the hypothesis of a neomorphosed, cavity-filling cement. The paper is, nevertheless, a most valuable contribution to the further understanding of a widely recognized and much discussed problem. It is to be hoped that it will draw further discussion and encourage more research. 


\section{References}

Allan, J. R. \& Matthews, R. K. (in the press). Carbon and oxygen isotopes as diagenetic and stratigraphic tools: data from surface and subsurface of Barbados, West Indies. Geology.

Bathurst, R. G. C. 1959. The cavernous structure of some Mississippian Stromatactis reefs in Lancashire, England. J. Geol. 67, 506-21.

Bathurst, R. G. C. 1971. Carbonate Sediments and their Diagenesis. Developments in Sedimentology 12. Elsevier Scientific Publ. Co. xix +658 pp.

Davies, G. R. (1977). Former magnesian calcite and aragonite submarine cements in upper Paleozoic reefs of the Canadian Arctic: a summary. Geology 5, 11-15.

Kendall, A. C. \& Tucker, M. E. 1973. Radiaxial fibrous calcite: a replacement after acicular carbonate. Sedimentology 20, 365-89.

Ross, R. J., Jaanusson, V. \& Friedman, I. 1975. Lithology and origin of Middle Ordovician calcareous mudmound at Meiklejohn Peak, southern Nevada. Prof. Paper U.S. geol. Surv. 871, 48 pp.

Sander, B. 1936. Beiträge zur Kenntniss der Anlagerungsgefüge (rhythmische Kalke und Dolomite aus der Trias). Miner. Petrog Mitt. 48, 27-209.

Department of Geology

R. G. C. BATHURST

University of Liverpool

England

11 th January 1977

\section{Average calc-alkali basalt}

SIR - There is much discussion at present on the nomenclature of igneous rocks, in particular that of the I.U.G.S. Subcommission on the Systematics of Igneous Rocks (Streckeisen, 1976a), and we feel it may aid discussion to clarify the term 'Central' basalt and to present a revised average chemical composition for calc-alkali basalts.

Le Maitre (1976a) and Streckeisen (1976 b) discussed methods of classifying the rocks of the calc-alkali volcanic suite, and one problem encountered is to decide what is understood by the term calc-alkali basalt. In 1954 the term 'Central' basalt was introduced by Nockolds for basaltic rocks with labradorite or more calcic plagioclase, which are found in association with typical calc-alkali andesites, dacites and rhyolites such as occur at Lassen Peak and Mount Shasta in the Cascades, and in other central volcanic complexes of the Caribbean Arc and the circum-Pacific belt. It did not include the Mull Porphyritic Central Magma (or high-alumina) type of Bailey et al. (1924). The purpose was to distinguish calc-alkali basalts from the tholeiitic and alkaline basalts of anorogenic regions. The main features were higher $\mathrm{SiO}_{2}$ and $\mathrm{Al}_{2} \mathrm{O}_{3}$, and lower $\mathrm{MgO}$ and total Fe.

The term 'Central' basalt is now considered to serve no further useful purpose, and it is recommended that the term be abandoned. The basalts of this group should be and are better known as calc-alkali basalts.

A new average chemical composition of calc-alkali basalt has been compiled (by S.R.N.). It is calculated from 48 mostly newer analyses than were used for the 1954 average, and only those with a low $\mathrm{H}_{2} \mathrm{O}$ content, fresh mineralogy, reliable alkali determination, and with normative plagioclase $A n_{33}$ or greater are included. The new figures are only slightly different, and still indicate that calc-alkali basalts have relatively high $\mathrm{SiO}_{2}$ and $\mathrm{Al}_{2} \mathrm{O}_{3}$, and low $\mathrm{MgO}$ and total Fe figures compared with other basalts, but that the silica saturation, $\mathrm{Fe} / \mathrm{Mg}$ ratio, and iron oxidation ratio $\left(\mathrm{Fe}^{2+} /\right.$ total $\mathrm{Fe}$ atoms $\left.=0.70\right)$ are about the same as non-alkaline basalts (Le Maitre, 1976 b).

The composition of the normative plagioclase is $\mathrm{An}_{59}$, the differentiation index (Thornton \& Tuttle, 1960) is 30.1, and the crystallization index (Poldervaart \& Parker, 1964) is 51.7. The latter index may serve to distinguish calc-alkali basalt from overall average basalts which have c.i. $<50$, but the d.i. is the same (Le Maitre, 1976 b). The normative colour index is 34 which, when plotted against normative plagioclase composition, is below that for 'within plate' tholeiitic basalts (commonly in range 40-60), but coincides with that given for basalts from the Aleutians and Cascades by Irvine \& Baragar (1971).

The new average composition for calc-alkali basalts also responds well when subjected to principal component analysis using the three eigenvectors given by Le Maitre (1976 a, table 1$)$. The resulting three 